\title{
Assessment of divine proportion in the cranial structure of individuals with Angle Class II malocclusion on lateral cephalograms
}

Marcos André dos Santos da Silva', Edmundo Médici Filho², Julio Cezar de Melo Castilho³ ${ }^{3}$ Cássia T. Lopes de Alcântara Gil ${ }^{4}$

Introduction: The study of the Divine Proportion $(\phi=1.618)$ began with the Greeks, having as main researchers the mathematician Pythagoras and the sculptor Phidias. In Dentistry, Ricketts (1981-82) was an early to study this issue.

Objective: This study proposed to evaluate how some cephalometric measures are presented in relation to the Divine Proportion, with the total of 52 proportions, formed by 28 cephalometric landmarks.

Methods: Lateral cephalograms of 40 Class II adults patients aging from 17 to 45 years (13 male and 27 female) were evaluated. The linear distances between the landmarks were measured using Radiocef Studio software.

Results: After statistical analysis, the data shown an average of 65,48\% in the Divine Proportion, $17,5 \%$ in the relation Ans-Op/V1S-DM16 and 97,5\% in the relations Na-Me/Na-PoNa e Na-PoNa/Na-Gn.

Conclusion: Among all cephalometric measurements investigated, the lower facial third and the dental arches showed the smallest percentages of Divine Proportion.

Keywords: Divine Proportion. Class II malocclusion. Cephalometry.

${ }^{1}$ Post-Graduation Student, UNICEUMA.

${ }^{2}$ Full Professor, School of Dentistry of São José dos Campos, UNESP.

${ }^{3}$ Associate Professor, School of Dentistry of São José dos Campos, UNESP.

${ }^{4}$ Professor and Executive Director of MetLife Dental.
How to cite this article: Silva MAS, Médici Filho E, Castilho JCM, Gil CTLA. Assessment of divine proportion in the cranial structure of individuals with Angle Class II malocclusion on lateral cephalograms. Dental Press J Orthod. 2012 MayJune;17(3):88-97.

Submitted: March 9, 2009 - Revised and accepted: August 16, 2009

» The authors report no commercial, proprietary, or financial interest in the products or companies described in this article.

Contact address: Marcos André dos Santos da Silva Centro Universitário do Maranhão - UniCEUMA

R. Josué Montello, 1 - Renascença II - Zip code: 65.075-120 - São Luís/MA - Brazil

E-mail: profdrmarcos@hotmail.com 


\section{INTRODUCTION}

At this moment human beings are increasingly concerned about esthetics, beauty and harmonious shapes, specially facial ones. ${ }^{4,23,24}$ Such concern exists since pre-historic times, from the Paleolithic period until now. ${ }^{2,4}$ Beauty is a vital force that acts on the development of our lives and the human mind has been relentlessly searching for beauty in the different populations and periods. ${ }^{4,23}$ The search for prettier shapes that may satisfy the individual represents the endless desire for perfection and balance, leading to the concept of design and esthetics. However, the evaluation of beauty may be relative and abstract, i.e. something that is inside the mind of each person.

The dental treatment should follow artistic and scientific regulations. The teeth must be esthetically pleasant and fully functional with other facial structures. Orthodontists should not solely move teeth and gingiva by the fast techniques or strictly apply conventional methods. There is no universal treatment for all patients, since this might not be in accordance with nature and arts. The final goal after achieve a normal occlusion should be an improvement in facial esthetics. If the proportions are distorted instead of being reestablished, the employed method may have been unsuccessful and shall affect the final outcome. The association of scientific knowledge, meticulous and systematic observation, application of beauty rules, daily training and effort to improve health of the patient and beauty allows the clinicians to promote the health and happiness of patients. ${ }^{18,24}$

The study of Divine Proportion was initiated by the Greeks, being the main researchers the mathematician Pythagoras and the sculptor Phidias. These investigators noticed that some findings were related to certain standards and numbers, which might explain the beauty and harmony observed in nature., ${ }^{9,10,11}$ The Divine Proportion is one of the most effective resources of esthetic proportionality available. It has been widely employed throughout the art history. The ancient Egyptians already knew the golden ratio and applied it in the construction of the pyramids. The Greeks employed it in their temples, the great artists in their paintings and sculptures, and even the great composers applied it in their works. The Divine Proportion may be used for morphological analysis and esthetic evaluation of the teeth and facial skeleton and soft tissues, since many proportions found and defined as beautiful from human point of view, or comfortable and pleasant from a physical standpoint, display this proportion. Therefore, it was indicated for analysis of the structural harmony and may be applied in the orthodontic treatment planning, as well as in the planning of maxillofacial and plastic surgeries. ${ }^{14,19}$ Thus, the search for an ideal esthetics might be scientifically conducted instead using subjective perceptions. ${ }^{18}$

The investigation of this issue calls the interest of different areas such as Orthodontics, Maxillofacial Surgery, Plastic Surgery and Esthetics. It has also been applied in cephalometric analyses by authors such as Ricketts, ${ }^{18}$ Zietsman et al, ${ }^{25} \mathrm{Gil},{ }^{8} \mathrm{Gil}$ and Medici Filho ${ }^{7}$ and Medici Filho at al ${ }^{14}$ who demonstrated the existence of Divine Proportion between different measurements of the human skull. According to Baker and Woods ${ }^{2}$, few studies have been published on the Divine Proportion observed in the measurements of human skull. This demonstrates the importance of the present study, which aimed at evaluating the Divine Proportion in lateral cephalograms of Class II adult subjects, who were not submitted to previous orthodontic treatment.

\section{MATERIAL AND METHODS}

The sample comprised lateral cephalograms of 40 untreated Class II adult individuals (13 males and 27 females), aging from 17 to 45 years, with an ANB angle larger than $6^{\circ}$ and no craniofacial deformities, syndromes or cleft lip and palate.

The work was carried out as follows:

» The radiographs were digitized and recorded in a CD by means of a Scanjet HP 4C scanner (HP, Washington, USA) with transparency adapter. The images were stored in a computer and analyzed on the Radiocef Studio software (Radiomemory, Belo Horizonte, Brazil). Two cephalometric analyses were created, namely the Lateral Divine Analysis 1 (LDAl) and Lateral Divine Analysis 2 (LDA2). They employed the same cephalometric points available on the software, 
besides some other landmarks suggested by Gil and Medici Filho ${ }^{12}$ and demonstrated in Figure 1 and Table 1. The linear measurements were measured on the Radiocef Studio software. The analyses LDAl and LDA2 comprised 52 factors each, and each factor of the LDAl was divided by the corresponding factor on the LDA2. For example, the factor \#1 of the LDA1 was divided by factor \#1 of the LDA2 and so on up to factor \#52 for verification of the presence or absence of Divine proportion in each radiograph. It should be highlighted that the larger value is always divided by the smaller value in order to facilitate the statistical calculations, i.e. the factors presented in LDAl would be in Divine Proportion with their corresponding factors in LDA2 if this division yielded values ranging from 1.431 to 1.853, as advocated by $\mathrm{Gil}^{8}$ in 2001.

"As an attempt to eliminate possible marking errors, each radiograph was traced twice, with a 15-day interval between them. Error calculation was conducted by the Intraclass Correlation Coefficient (ICC), which represents the total estimate of variability induced by individual variations. This coefficient estimates the degree of agreement between two values achieved in distinct moments. ${ }^{12}$ The examinations were individually analyzed by the author by means of the LDAl and LDA2, applied for each patient (Tables 2 and 3).

Statistical analysis of the linear measurements achieved by means of the LDAl and LDA2 calculated on the Radiocef Studio software were conducted in order to observe the presence or absence of Divine Proportion in the human skull.

\section{STATISTICAL ANALYSIS}

Statistical analysis of the data was based on the following concept of divine proportion: One pair of measurements (A, B) is in Divine Proportion if $\mathrm{A} / \mathrm{B}=1.618$, where $A>B$. The range from 1.431 to 1.853 was employed to assess the pairs of measurements in Divine Proportion, as suggested by Gil. ${ }^{7}$

The Minitab 13 software (Minitab Inc, State College, USA) was employed for calculation of the divisions of the factors of LDAl by those of LDA2 for each radiograph. It should be highlighted that this division was also performed by division of the largest value by the smallest value. After calculation of these proportions, the Statistix for Windows 7.0 software (Analytical Software, Tallahassee, USA) was used to submit the data to Descriptive Statistical Analysis (mean, standard deviation and median) at a confidence interval of $95 \%$. This software also allowed calculation of the frequency distribution in order to establish how many factors in each radiograph were within the range established and, therefore, in Divine Proportion (Tables 1 and 2) (Fig 2).

\section{RESULTS}

Results are shown in Figure 2 and Tables 1 and 2.

\section{DISCUSSION}

The study of Divine Proportion in Dentistry was initiated in the 70s and 80s and was mainly conducted by Torres ${ }^{22}$ and Ricketts. ${ }^{18,19}$ Investigation of this subject has provided important contributions to the improvement and enhancement of the diagnosis and treatment planning of the patients, providing dentists a further instrument to evaluate whether shape, harmony, esthetics and craniofacial proportion are present. ${ }^{7,8,14,18,19,22,23,24}$

The sample of the present study comprised 40 lateral cephalograms of 40 untreated Class II adult subjects (13 males and 27 females) with more than 17 years of age. Ricketts ${ }^{5}$ employed a sample of 30 lateral cephalograms of adult Peruvian male patients with normal occlusion and no admixture of races for assessment of the presence of Divine Proportion. Gil ${ }^{8}$ and Gil and Medici Filho ${ }^{7}$ observed the Golden Proportion in the cranial structures on a population of 23 untreated adult subjects with normal occlusion, of both genders, by means of lateral, frontal and axial cephalograms.

Some studies on Divine Proportion have regarded this method as effective for evaluation of beauty, harmony and proportion in objects such as paintings, buildings and even music compositions, as well as in several fields of science. Hintz and Nelson $^{9}$, Piehl ${ }^{17}$ and Oliveira Junior ${ }^{15}$ concluded that noticeably prettier individuals presented a correspondence of $73.33 \%$ with the eight esthetic rules, 
Table 1 - Landmarks constituting the LDA1 and LDA2 analyses.

\section{\# Abbreviation Definition of anatomical location}
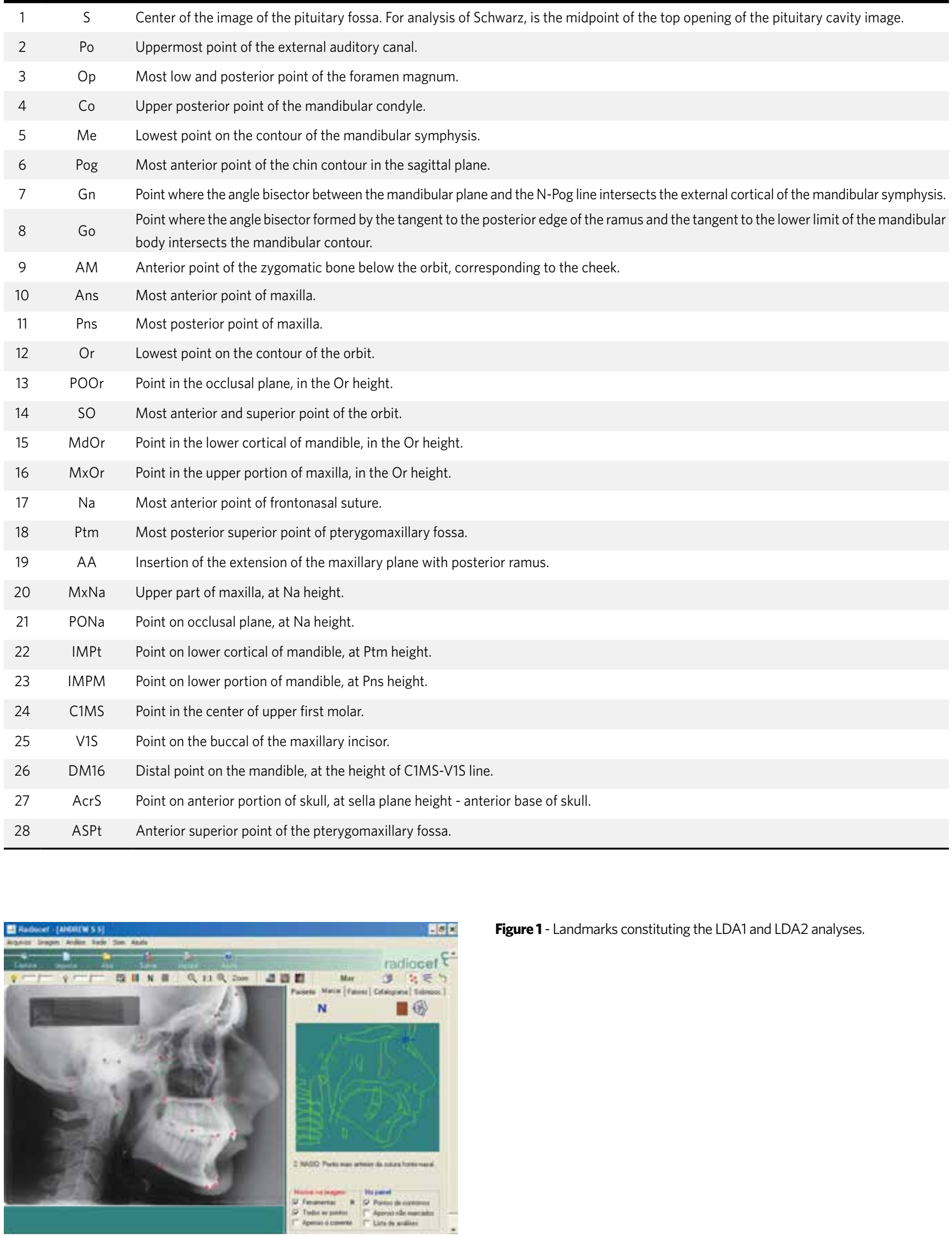

Figure 1 - Landmarks constituting the LDA1 and LDA2 analyses. 
Table 2 - Lateral Divine Analysis 1.

\section{Computerized Cephalometrics - Lateral Divine Analysis 1}

Patient:

Orthodontist:

\begin{tabular}{|c|c|c|c|c|}
\hline & Factors & Landmarks 1 & $\begin{array}{l}\text { Value } \\
\text { found }\end{array}$ & Landmarks 2 \\
\hline 1 & $\mathrm{Na}-\mathrm{Me}$ & $\mathrm{Na}$ & 0.00 & $\mathrm{Me}$ \\
\hline 2 & $\mathrm{Na}-\mathrm{Me}$ & $\mathrm{Na}$ & 0.00 & $\mathrm{Me}$ \\
\hline 3 & $\mathrm{Na}-\mathrm{Me}$ & $\mathrm{Na}$ & 0.00 & $\mathrm{Me}$ \\
\hline 4 & Ans-Me & Ans & 0.00 & $\mathrm{Me}$ \\
\hline 5 & Ans-Me & Ans & 0.00 & $\mathrm{Me}$ \\
\hline 6 & Na-Ans & $\mathrm{Na}$ & 0.00 & Ans \\
\hline 7 & $\mathrm{Na}-\mathrm{Ans}$ & $\mathrm{Na}$ & 0.00 & Ans \\
\hline 8 & Na-Ans & $\mathrm{Na}$ & 0.00 & Ans \\
\hline 9 & $\mathrm{Na}-\mathrm{Ans}$ & $\mathrm{Na}$ & 0.00 & Ans \\
\hline 10 & Na-Ans & $\mathrm{Na}$ & 0.00 & Ans \\
\hline 11 & $\mathrm{Na}-\mathrm{Ans}$ & $\mathrm{Na}$ & 0.00 & Ans \\
\hline 12 & Na-Ans & $\mathrm{Na}$ & 0.00 & Ans \\
\hline 13 & $\mathrm{Na}$-Poor & $\mathrm{Na}$ & 0.00 & Poor \\
\hline 14 & $\mathrm{Na}$-Poor & $\mathrm{Na}$ & 0.00 & Poor \\
\hline 15 & Na-Poor & $\mathrm{Na}$ & 0.00 & Poor \\
\hline 16 & Na-Poor & $\mathrm{Na}$ & 0.00 & Poor \\
\hline 17 & $\mathrm{Na}$-Poor & $\mathrm{Na}$ & 0.00 & Poor \\
\hline 18 & Pt-IMPt & $\mathrm{Pt}$ & 0.00 & IMPt \\
\hline 19 & Pt-IMPt & $\mathrm{Pt}$ & 0.00 & IMPt \\
\hline 20 & Pt-IMPt & $\mathrm{Pt}$ & 0.00 & IMPt \\
\hline 21 & Pns-ImPm & Pns & 0.00 & $\mathrm{ImPm}$ \\
\hline 22 & Pns-ImPm & Pns & 0.00 & $\mathrm{ImPm}$ \\
\hline 23 & SO-Or & so & 0.00 & Or \\
\hline 24 & SO-Or & so & 0.00 & Or \\
\hline 25 & SO-Or & so & 0.00 & Or \\
\hline 26 & A-Pog & $A$ & 0.00 & Pog \\
\hline 27 & A-Pog. & A & 0.00 & Pog. \\
\hline 28 & A-Pog. & A & 0.00 & Pog. \\
\hline 29 & A-Pog. & A & 0.00 & Pog. \\
\hline 30 & A-Pog. & $A$ & 0.00 & Pog. \\
\hline 31 & Ans-Pns & Ans & 0.00 & Pns \\
\hline 32 & Ans-Pns & Ans & 0.00 & Pns \\
\hline 33 & Ans-Pns & Ans & 0.00 & Pns \\
\hline 34 & Ans-Pns & Ans & 0.00 & Pns \\
\hline 35 & Ans-Pns & Ans & 0.00 & Pns \\
\hline 36 & Ans-Pns & Ans & 0.00 & Pns \\
\hline 37 & Pog-Op & Pog & 0.00 & Op \\
\hline 38 & Pog-Op & Pog & 0.00 & Op \\
\hline 39 & Pog-Op & Pog & 0.00 & Op \\
\hline 40 & Pog-Op & Pog & 0.00 & Op \\
\hline 41 & $\mathrm{Na}-\mathrm{Op}$ & $\mathrm{Na}$ & 0.00 & Op \\
\hline 42 & $\mathrm{Na}-\mathrm{Op}$ & $\mathrm{Na}$ & 0.00 & Op \\
\hline 43 & $\mathrm{Na}-\mathrm{Op}$ & $\mathrm{Na}$ & 0.00 & Op \\
\hline 44 & $\mathrm{Na}-\mathrm{Op}$ & $\mathrm{Na}$ & 0.00 & Op \\
\hline 45 & $\mathrm{Na}-\mathrm{Op}$ & $\mathrm{Na}$ & 0.00 & Op \\
\hline 46 & Ans-Op & Ans & 0.00 & Op \\
\hline 47 & Ans-Op & Ans & 0.00 & Op \\
\hline 48 & Ans-Op & Ans & 0.00 & Op \\
\hline 49 & V1S-C1MS & V1S & 0.00 & C1MS \\
\hline 50 & V1S-C1MS & V1S & 0.00 & C1MS \\
\hline 51 & Mdor-Poor & Mdor & 0.00 & Poor \\
\hline 52 & Mdor-Poor & Mdor & 0.00 & Poor \\
\hline
\end{tabular}

Table 3 - Lateral Divine Analysis 2.

\section{Computerized Cephalometrics - Lateral Divine Analysis 2}

Patient: Age: Sex:

Orthodontist:

Date:

\begin{tabular}{|c|c|c|c|c|}
\hline & Factors & Landmarks 1 & $\begin{array}{l}\text { Value } \\
\text { found }\end{array}$ & Landmarks 2 \\
\hline 1 & Ans-Me & Ans & 0.00 & $\mathrm{Me}$ \\
\hline 2 & $\mathrm{Na}-\mathrm{PoNa}$ & $\mathrm{Na}$ & 0.00 & $\mathrm{PoNa}$ \\
\hline 3 & Pt-IMPt & $\mathrm{Pt}$ & 0.00 & IMPt \\
\hline 4 & $\mathrm{Na}-\mathrm{Gn}$ & $\mathrm{Na}$ & 0.00 & Gn \\
\hline 5 & Co-Gn & Co & 0.00 & Gn \\
\hline 6 & Ans-AA & Ans & 0.00 & $\mathrm{AA}$ \\
\hline 7 & Go-Pog & Go & 0.00 & Pog \\
\hline 8 & $\mathrm{Na}-\mathrm{PoNa}$ & $\mathrm{Na}$ & 0.00 & $\mathrm{PoNa}$ \\
\hline 9 & Or-Me & Or & 0.00 & $\mathrm{Me}$ \\
\hline 10 & V1S-AA & V1S & 0.00 & $\mathrm{AA}$ \\
\hline 11 & Pns-Op & Pns & 0.00 & Op \\
\hline 12 & S-Acrs & $S$ & 0.00 & Acrs \\
\hline 13 & Co-Gn & Co & 0.00 & Gn \\
\hline 14 & $\mathrm{Na}-\mathrm{Gn}$ & $\mathrm{Na}$ & 0.00 & $\mathrm{Gn}$ \\
\hline 15 & Pns-IMPM & Pns & 0.00 & IMPM \\
\hline 16 & $\mathrm{Na}-\mathrm{MxN}$ & $\mathrm{Na}$ & 0.00 & $M \times N$ \\
\hline 17 & Or-Poor & Or & 0.00 & Poor \\
\hline 18 & Co-Gn & Co & 0.00 & $\mathrm{Gn}$ \\
\hline 19 & $\mathrm{Na}-\mathrm{Gn}$ & $\mathrm{Na}$ & 0.00 & Gn \\
\hline 20 & Pns-IMPM & Pns & 0.00 & IMPM \\
\hline 21 & Go-Pog & Go & 0.00 & Pog \\
\hline 22 & Co-Am & Co & 0.00 & $\mathrm{Am}$ \\
\hline 23 & Mxor-So & Mxor & 0.00 & So \\
\hline 24 & Mxor-Mdor & Mxor & 0.00 & Mdor \\
\hline 25 & Ans-Pog & Ans & 0.00 & Pog \\
\hline 26 & Or-Me & Or & 0.00 & $\mathrm{Me}$ \\
\hline 27 & Po-Na & Po & 0.00 & $\mathrm{Na}$ \\
\hline 28 & V1S-C1MS & V1S & 0.00 & C1MS \\
\hline 29 & V1S-AA & V1S & 0.00 & AA \\
\hline 30 & V1S-AA & V1S & 0.00 & $A A$ \\
\hline 31 & V1S-C1MS & V1S & 0.00 & C1MS \\
\hline 32 & Op-Pns & Op & 0.00 & Pns \\
\hline 33 & Or-Me & Or & 0.00 & $\mathrm{Me}$ \\
\hline 34 & SO-Poor & so & 0.00 & Poor \\
\hline 35 & Ans-AA & Ans & 0.00 & $A A$ \\
\hline 36 & Op-Pns & Op & 0.00 & Pns \\
\hline 37 & Op-ASPt & Op & 0.00 & ASPt \\
\hline 38 & Or-Me & Or & 0.00 & $\mathrm{Me}$ \\
\hline 39 & Go-Pog & Go & 0.00 & Pog \\
\hline 40 & V1S-AA & V1S & 0.00 & $\mathrm{AA}$ \\
\hline 41 & Op-Pns & Op & 0.00 & Pns \\
\hline 42 & SO-Poor & so & 0.00 & Poor \\
\hline 43 & Or-Me & Or & 0.00 & $\mathrm{Me}$ \\
\hline 44 & Go-Pog & Go & 0.00 & Pog \\
\hline 45 & V1S-AA & V1S & 0.00 & $\mathrm{AA}$ \\
\hline 46 & Op-Pns & Op & 0.00 & Pns \\
\hline 47 & Go-Pog & Go & 0.00 & Pog \\
\hline 48 & V1S-AA & V1S & 0.00 & $\mathrm{AA}$ \\
\hline 49 & Ans-Pns & Ans & 0.00 & Pns \\
\hline 50 & Ans-Pog & Ans & 0.00 & Pog \\
\hline 51 & Mxor-Mdor & Mxor & 0.00 & Mdor \\
\hline 52 & Mxor-Poor & Mxor & 0.00 & Poor \\
\hline
\end{tabular}




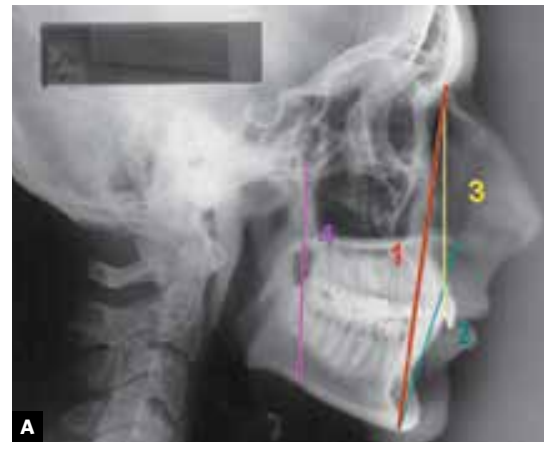

\begin{tabular}{|c|c|c|}
\hline $\mathrm{Na}-\mathrm{Me} / \mathrm{Ans}-\mathrm{Me}$ & $\mathrm{Na}-\mathrm{Me} / \mathrm{Na}-\mathrm{PoNa}$ & $\mathrm{Na}-\mathrm{Me} / \mathrm{Ptm}-\mathrm{IMPt}$ \\
\hline $85 \%$ & $97.5 \%$ & $80 \%$ \\
\hline
\end{tabular}

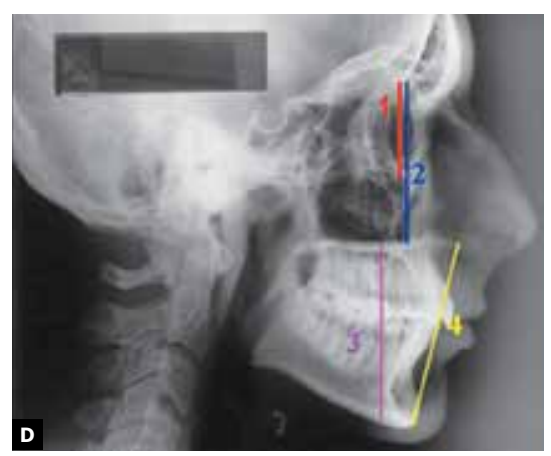

\begin{tabular}{|c|c|c|}
\hline SO-Or/Mxor-SO & SO-Or/Mxor-Mdor & SO-Or/Ans-Pog \\
\hline $70 \%$ & $45 \%$ & $55 \%$ \\
\hline
\end{tabular}

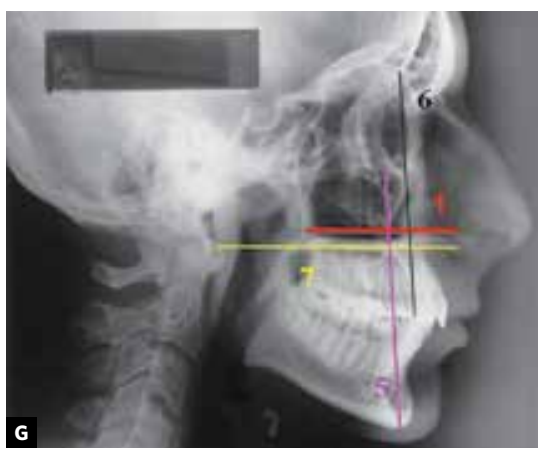

\begin{tabular}{|c|c|c|}
\hline Ans-Pns/Or-Me & Ans-Pns/SO-Poor & Ans-Pns/Ans-AA \\
\hline $42.5 \%$ & $65 \%$ & $52.5 \%$ \\
\hline
\end{tabular}

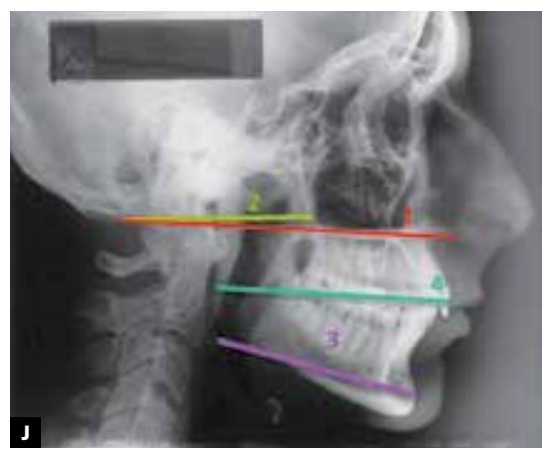

\begin{tabular}{|c|c|c|}
\hline Ans-Op/Op-Pns & Ans-Op/Go-Pog & Ans-Op/V1s-DM16 \\
\hline $92.5 \%$ & $80 \%$ & $17,5 \%$ \\
\hline
\end{tabular}
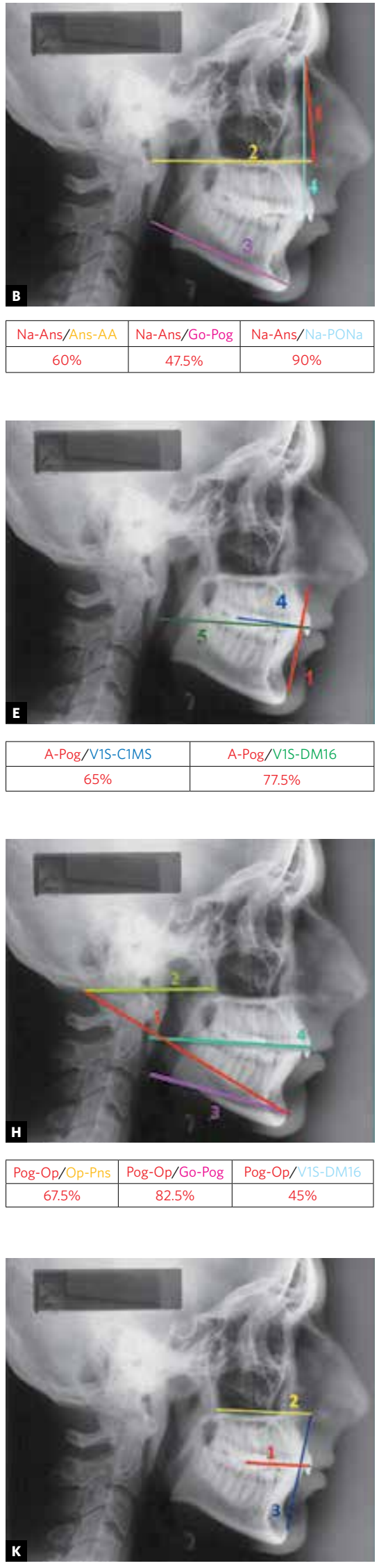

\begin{tabular}{|c|c|}
\hline V1S-C1MS/Ans-Pns & V1S-C1MS/Ans-Pog \\
\hline $30 \%$ & $62.5 \%$ \\
\hline
\end{tabular}
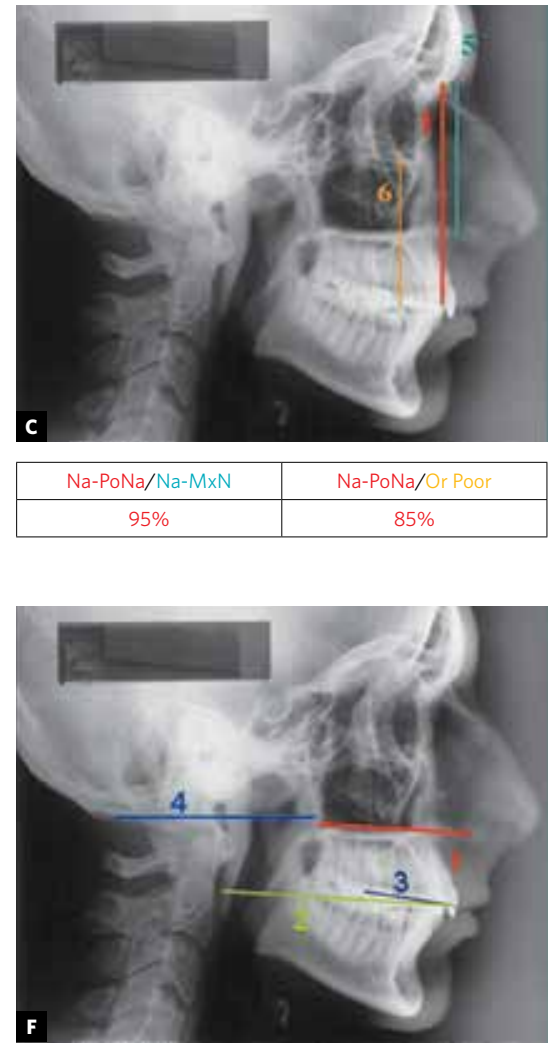

\begin{tabular}{|c|c|c|}
\hline Ans-Pns/VIS-DM16 & Ans-Pns/VIs-CaMs & Ans-Pns/Op-Pns \\
\hline $52.5 \%$ & $30 \%$ & $42.5 \%$ \\
\hline
\end{tabular}

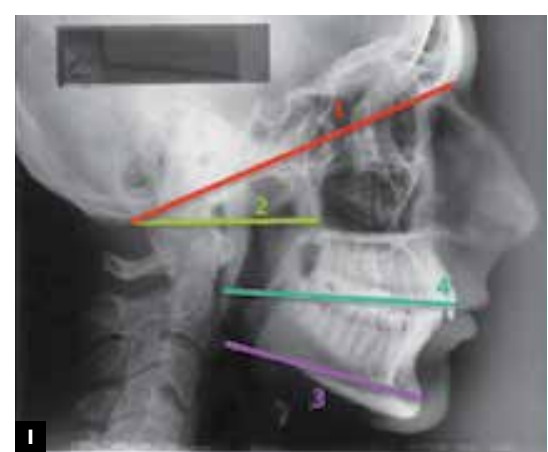

\begin{tabular}{|c|c|c|}
\hline $\mathrm{Na} a \mathrm{Op} / \mathrm{Op}-\mathrm{Pns}$ & $\mathrm{Na}-\mathrm{Op} / \mathrm{Go}-\mathrm{Pog}$ & $\mathrm{Na}-\mathrm{Op} / \mathrm{V} 1 \mathrm{~S}-\mathrm{DM} 16$ \\
\hline $75 \%$ & $60 \%$ & $55 \%$ \\
\hline
\end{tabular}

Figure 2 - Proportions found relating the cephalometric factors. 


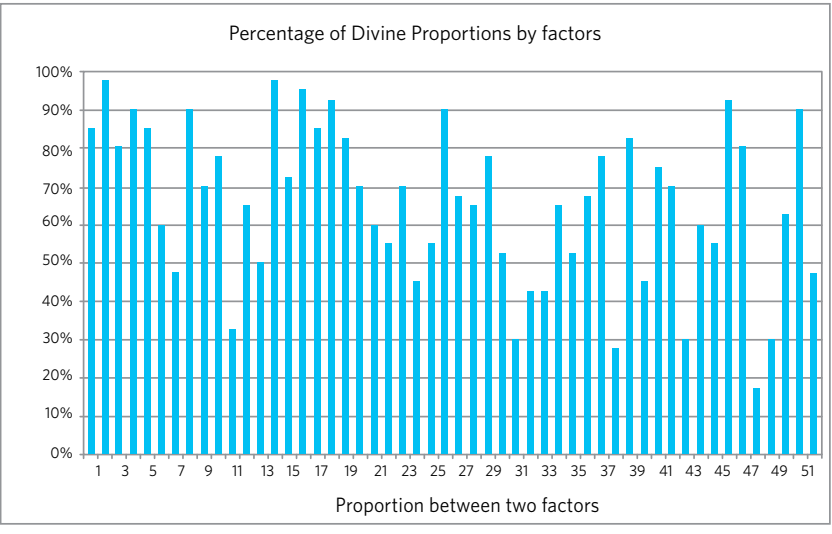

Figure 3 - Graphic of percentages of divine proportion between factors.

including some of Divine Proportion, whereas the non-pretty subjects displayed a correspondence of just $38.33 \%$. The present study did not evaluate the patient's attractiveness, since our sample suggests the presence of a facial esthetic imbalance secondary to the Angle Class II malocclusion present.

Ricketts, ${ }^{18}$ Zietsman et al, ${ }^{25}$ Garbin, ${ }^{5,6}$ Piccin, ${ }^{16}$ Snow, ${ }^{21}$ Araújo et al ${ }^{1}$ and Oliveira Junior ${ }^{15}$ conducted specific investigations on the oromaxillofacial structures and also found Divine Proportion. For example, Ricketts ${ }^{18}$ observed this proportion in horizontal and vertical measurements. Gil, ${ }^{8} \mathrm{Gil}$ and Medici Filho ${ }^{7}$ and Medici Filho ${ }^{14}$ found the presence of several measurements in Golden Proportion, which were related to each other in several manners and provided the human skull with an effective balance. These findings strongly suggested that the skull, as well as other structures in nature, follows the laws of conservation of energy and thus is a very effective structure in both shape and composition. In the present study, many structures were found to be in Divine Proportion, as demonstrated on the tables and figures.

Radiographic cephalometrics consists on the measurement of physical, linear and angular dimensions in skull radiographs. It is a very good auxiliary and supplementary instrument for diagnosis and may even be regarded as essential for observation of growth and evaluation of orthodontic treatments. This technique has been and still is the most widely employed for assessment of the facial growth, facial profile and also of the relationship

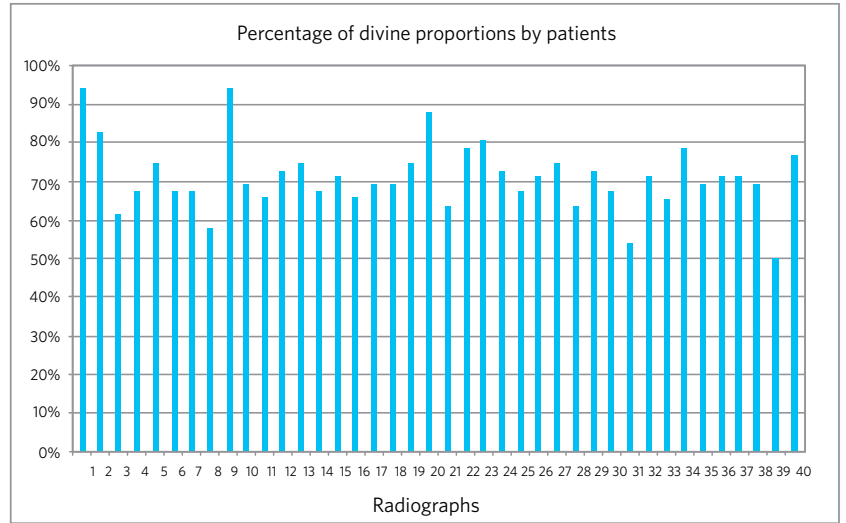

Figure 4 - Graphic of percentages of divine proportion between patients.

between maxilla and mandible in human beings. Some authors have employed it to investigate the presence of Divine Proportion in the oromaxillofacial structures and achieved satisfactory outcomes (Ricketts, ${ }^{18}$ Zietsman et al, ${ }^{25}$ Garbin, ${ }^{5,6}$ Araújo et al, ${ }^{1}$ Baker and Woods, ${ }^{4}$ Gil and Medici Filho, ${ }^{7}$ Medici Filho et $\mathrm{al}^{14}$ ). The present study comprised evaluation of measurements of the human skull structure by means of landmarks and factors measured on lateral cephalograms, by means of a computerized cephalometric software called Radiocef Studio. According to Martins ${ }^{13}$ and Brangeli, ${ }^{3}$ the advent of informatics and its application in clinical cephalometrics has provided high-technology resources for the achievement of elements of diagnosis and also for manipulation of such elements, for the accomplishment of projections, analyses and treatment simulations, enhancing and facilitating selection of the best therapeutic approach. On the other hand, there may be errors in the cephalometric analyses with employment of the computer, leading to doubtful measurements with employment of this method. Error control is fundamental for the outcomes of cephalometric investigations to be valid. ${ }^{10}$

Now we are going to discuss the results of Divine Proportions observed in the present study, which shall be divided by groups of factors of cephalometric measurements in order to make interpretation of such outcomes easier.

Correlation between vertical distances such as $\mathrm{Na}-\mathrm{Me}$ / ANS-Me, Na-Me / Na-PoNa, Na-Me / PtmIMPt (Fig 2A) revealed Divine Proportion in more 
than $80 \%$ of the sample, suggesting that even in the presence of Class II malocclusions the muscle forces that define the vertical dimension were present and could provide balance, harmony and even a proper facial proportion. It should be noticed that Na-Me represents the anterior facial height of the patient in frontal view and was in Divine Proportion with the intermaxillary distance (ANS-Me) when in occlusion. In 1982, Ricketts ${ }^{18}$ found Divine Proportion when related similar measurementes to $\mathrm{Na}-\mathrm{Me}$ and ANS-Me in soft tissue, using photographs of beautiful women (models) of different races.

The present results are also in agreement with $\mathrm{Gil}^{8}$ and Gil and Medici Filho, ${ }^{7}$ who also observed a percentage of Golden Proportion above $80 \%$ in an evaluation of lateral cephalograms of patients with normal occlusion.

Relationship between measurements comprising just one point at the maxilla and another at the skull, Na-ANS / Na-PONa, (Fig 2B), revealed the presence of Divine Proportion in $90 \%$ of the sample. However, the observation of the correlation Na-ANS / ANS-AA, on which one cephalometric point is located at the mandible (AA), the percentage of Divine Proportion was decreased to $60 \%$ of the sample. Moreover, the correlation Na-ANS / Go-Pog, which related one factor with one point at the maxilla and another at the skull to another factor measured just in the mandible, revealed the presence of Divine Proportion in just $47.5 \%$ of the cases. These values are different from the findings of Gil, ${ }^{8}$ and Gil and Medici Filho, ${ }^{7}$ which observed Divine Proportion in such relationship in more than $80 \%$ of the sample. This difference might be assigned to a retruded mandible in relation to the maxilla as observed in Class II patients.

Figure 2C demonstrates the presence of Divine Proportion in $95 \%$ of the patients for $\mathrm{Na}-\mathrm{PoNa} /$ $\mathrm{Na}-\mathrm{MxN}$ and $85 \%$ of the patients for $\mathrm{Na}-\mathrm{PoNa} / \mathrm{Or}-$ Poor; these factors are located just at the maxilla and facial bones and therefore are not influenced by the disproportion existing between maxilla and mandible of Class II patients. These observations were in agreement with $\mathrm{Gil},{ }^{8} \mathrm{Gil}$ and Medici Filho. ${ }^{7}$

The measurements SO-Or / Mxor-SO (Fig 2D), which are measurements of the maxilla and upper facial third, displayed a higher percentage of Divine
Proportion (70\%) than the measurements SO-Or / Mxor-Mdor and SO-Or / ANS-Pog, 45\% and 55\% respectively, which comprise maxillary and mandibular measurements and therefore are more susceptible to the alterations observed in subjects with malocclusion. For that reason, these outcomes disagree with the findings of Gil, ${ }^{8}$ and Gil and Medici Filho. ${ }^{7}$

Divine Proportion was observed in $65 \%$ of cases for the A-Pog / V1S-C1MS and in $77.5 \%$ for A-Pog /V1S-DM16 (Fig 2E). These factors are prone to variations that are directly related to occlusal disturbances, since they are horizontal factors on the maxilla and thus may vary with the mandibular retraction in relation to the maxilla. Another possible explanation for this reduced ratio of Divine Proportion might be the involvement of factors based on points on the teeth, which are similarly influenced by malocclusions. Thus, these percentages of Divine Proportions were smaller than those observed by $\mathrm{Gil}^{8}$ and Gil and Medici Filho, ${ }^{7}$ who found the presence of Divine Proportion in more than $80 \%$ of the subjects in skeletal and dental measurements and also on dental and skeletal measurements on the maxillary incisors.

The comments on Figure 2E are confirmed in Figure 2F, which demonstrates presence of Divine Proportion for the horizontal measurements in $42.5 \%$ for the ANS-PNS / Op-Pns and $52.5 \%$ for the ANS-PNS / V1S-DM16, i.e., factors influenced by the anterior posterior relationship between maxilla and mandible, and in $30 \%$ for ANS-PNS / V1S-C1MS, which also involved the teeth.

Araújo et $\mathrm{al}^{1}$ observed that the patients presented different responses to treatment and found statistical differences in the outcomes between the pre- and post-operative data in the proportions A-1 / 1-Pm and Co-Xi / Xi-Pm. Yet this did not occur for the proportion Pfr-A / A-Pm, which presented a significant difference, revealing no alterations with surgery from an esthetic point of view. The authors explained that the vertical measurements, compared to the Co-Xi / Xi-PM measurement, displayed a smaller alteration with the mandibular advancement, which provides a larger change in anterior posterior than in vertical direction.

As regards the ratio ANS-PNS / V1S-ClMS, there may also be a larger growth of the maxillary 
base ANS-PNS in relation to the arch size VlSClMS, which leads to such disharmony. Similarly, Figure $2 \mathrm{G}$ reveals presence of Divine Proportion in $42.5 \%$ for ANS-PNS / Or-Me, $65 \%$ for ANS-PNS / SO-Poor and $52.5 \%$ for ANS-Pns / ANS-AA. Therefore, the ratios between cephalometric factors displayed a smaller percentage of Divine Proportion than reported by $\mathrm{Gil}^{8}$ and Gil and Medici Filho. ${ }^{7}$

According to $\mathrm{Gil},{ }^{8}$ when one factor in the groups of measurements Pog-Op, Na-Op and ANS-Op is in proportion with one of these measurements, it shall also be in proportion with the other two measurements. The three measurements were regarded as equal in his study. However, in the present study the relationship between the factors PogOp, Na-Op and ANS-Op with each of the factors Op-PNS, Go-Pog and V1S-DM16 (Fig 2H, I and J) presented different results, as shown in Table 4.

Figure 2L represents positioning of the maxillary incisor and maxillary first molar, which refer to the anterior posterior positioning of the tooth, an important aspect for Class II patients. Correlation between factors of horizontal dimensions, (V1S-ClMS/ANS-PNS) revealed Divine Proportion in $30 \%$ of the patients, yet the correlation between one horizontal and one vertical factor (V1S-C1MS / ANS-Pog) displayed a percentage of Divine Proportion of $62.5 \%$. These relationships displayed a larger percentage of Divine Proportion in the study of $\mathrm{Gil}^{8}$ and Gil and Medici Filho. ${ }^{7}$

In general, calculation of the mean of percentages of the 52 correlations between the cephalometric factors investigated revealed a rate of $65.48 \%$ of Divine Proportion, different from the outcomes of $\mathrm{Gil}^{8}$ and Gil and Medici Filho, ${ }^{7}$ who found a percentage above $80 \%$. Moreover, Divine Proportion was observed in $17.5 \%$ for the ANS-Op/V1S-DM16 relationship and $97.5 \%$ for the $\mathrm{Na}-\mathrm{Me} / \mathrm{Na}-\mathrm{PoNa}$ and $\mathrm{Na}-\mathrm{PoNa} / \mathrm{Na}-\mathrm{Gn}$ correlations, which were the
Table 4 - Percentage of ratios observed upon relationship between PogOp, Na-Op and ANS-Op factors with each of the factors Op-PNS, Go-Pog and V1S-DM16.

\begin{tabular}{lll}
\hline Pog-Op / Op-Pns & Pog-Op / Go-Pog & Pog-Op /V1S-DM16 \\
\hline $67.5 \%$ & $82.5 \%$ & $45 \%$ \\
Na-Op / Op-Pns & Na-Op /Go-Pog & Na-Op /V1S-DM16 \\
$75 \%$ & $60 \%$ & $55 \%$ \\
Ans-Op /Op-Pns & Ans-Op /Go-Pog & Ans-Op /V1S-DM16 \\
$92.5 \%$ & $80 \%$ & $17.5 \%$ \\
\hline
\end{tabular}

lowest and highest percentages of Divine Proportion observed in the present sample, respectively.

During the development of this study and in agreement with the literature review, it could be noticed that even though the discovery of the Divine Proportion is very old, its study and application in health specialties and mainly in Dentistry are based on few studies. Investigations on this subject have been conducted since the ancient Greece, yet just in 1982 Ricketts $^{18}$ demonstrated the presence of Divine Proportions in lateral cephalograms. As described, the Divine Proportion may play a very important role in the evaluation of diagnosis and also as an auxiliary therapeutical tool in Dentistry.

\section{CONCLUSIONS}

Based on these methods and on the analysis of the results achieved, the following could be concluded on the cranial structure of untreated Class II adult subjects:

» There was a mean percentage of $65.48 \%$ of the cephalometric measurements in Divine Proportion.

»Among all cephalometric measurements investigated, the lower third of the head, as well as the dental arches of the individuals in this sample, were the areas on which the proportions displayed the smallest percentages of Divine Proportion. 


\section{REFERENCES}

1. Araujo MM, Passer LA, Araujo A. Análise cefalométrica pré e pós-operatória das proporções divinas de Fibonacci em pacientes submetidos a avanço mandibular. Rev Dental Press Ortodon Ortop Facial. 2001 Nov-Dez;6(6):29-36.

2. Baker BW, Woods MG. The role of the divine proportion in the esthetic improvement of patients undergoing combined orthodontic/orthognathic surgical treatment. Int J Adult Orthodon Orthognath Surg. 2001;16(2):108-20.

3. Brangeli LAM, Henriques JFC, Vasconcelos MHF, Janson GRP. Estudo comparativo da análise cefalométrica pelo método manual e computadorizado. Rev Assoc Paul Cir Dent. 2000 maio-jun;54(3):234-41.

4. Colombini NEP. Cirurgia ortognática e cirurgia estético-funcional. 2003. [cited 2003 Jan 07]. Available from: http://www.sosdoutor.com.br /sosbucomaxilo facial/defeitos.asp.

5. Garbin AJl. Análise das proporções divinas em telerradiografias de perfil de pacientes submetidos à cirurgia de retroposicionamento mandibular [Tese de doutorado]. Piracicaba (SP): Universidade Estadual de Campinas, Faculdade de Odontologia de Piracicaba; 1999.

6. Garbin AJI, Passeri LA. Análise das proporções divinas de Fibonacci, em telerradiografias de perfil em pacientes dotados de oclusão normal. Ortodontia, 1999;32(3):29-40

7. Gil CTLA, Medici Filho E. Estudo da proporção áurea na arquitetura craniofacial de indivíduos adultos com oclusão normal, a partir de telerradiografias axiais, frontais e laterais. Ortodontia. 2002 abr-jun;35(2):69-84.

8. Gil CTLA. Proporção áurea craniofacial. São Paulo (SP): Ed. Santos; 2001

9. Hintz JM, Nelson TM. Haptic aesthetic value of the golden section. Br J Psychol. 1971 May;62(2):217-23.

10. Kamoen A, Dermaut $L$, Verbeeck $R$. The clinical significance of error measurement in the interpretation of treatment results. Eur J Orthod. 2001 Oct;23(5):569-78.

11. Knott R. Fibonacci number and golden section - Department of Mathematical and Computing Science at the University of Surrey. [cited 2001 Jul 07]. Available from: http://www.mcs.surrey.ac.uk/Personal/R.Knott/ Fibonacci/fib.html.
12. Loffredo LCM. Estudo da reprodutibilidade de informaç̃es na área de saúde [tese de doutorado]. Araraquara (SP): Universidade Estadual Paulista, Faculdade de Odontologia de Araraquara; 1996

13. Martins LP, Pinto AS, Martins JCR, Mendes AJD. Erro de reprodutibilidade das medidas das análises cefalométricas de Steiner e Ricketts, pelo método convencional e método computadorizado. Rev Ortodon. 1995 Out;28(5): 4-17.

14. Medici Filho E, Martins MV, dos Santos da Silva MA, Castilho JC, de Moraes LC, Gil CT. Divine proportions and facial esthetics after manipulation of frontal photographs. World J Orthod. 2007 Summer;8(2):103-8.

15. Oliveira Junior OB. Construtores de sorriso - ciência ou arte? [internet] 2003; [cited 2003 Feb 15]. Available from: http://www.apcdriopreto.com.br /art_ cientificos2.asp? código $=6$

16. Piccin MR. Verificação da proporção divina da face de pacientes totalmente dentados [Dissertação]. Piracicaba (SP): Universidade Estadual de Campinas, Faculdade de Odontologia de Piracicaba; 1997.

17. Piehl J. The golden section: the "true" ratio? Percept Mot Skills. 1978 Jun;46(3 Pt 1):831-4.

18. Ricketts RM. The biologic significance of the divine proportion and Fibonacci series Am J Orthod. 1982 May;81(5):351-70.

19. Ricketts RM. The golden divider. J Clin Orthod. 1981 Nov;15(11):752-9.

20. Ricketts RM. Perspectives in the clinical application of cephalometrics. The first fifty years. Angle Orthod. 1981 Apr;51(2):115-50.

21. Snow SR. Esthetic smile analysis of maxillary anterior tooth width: the golden percentage. J Esthet Dent. 1999;11(4):177-84.

22. Torres R. Crecimiento armonioso y la divina proporción. Divulg Cult Odont. 1970 Jun;162(3):3-13.

23. Wuerpel EH. The inspiration of beauty. Angle Orthod. 1932 Out;2(4):201-18.

24. Wuerpel EH. On facial balance and harmony. Angle Orthod. 1937;7(2):81-9.

25. Zietsman ST, Wiltshire WA, Coetzee CE. The divine proportion and the cranial base. J Dent Res. 1997;76(1202): 831-4. 